\title{
Consumers' Perception of Barriers Effecting Green Purchase Behavior: Instrument Assessment
}

\author{
Azhan Hasan", Rabia Irfan, Zullina H. Shaari and Md. Akhir M Sharif \\ Universiti Teknologi Petronas, Department of Management and Humanities, 32610, Bander Seri Iskandar, Perak, Malaysia
}

\begin{abstract}
With the emergence of green consumerism, the trend of "going green" has now prolonged to the Asian region, including Malaysia. Despite most of Malaysians have shown great concern for environmental issues; however, the green buying behavior among Malaysians is not encouraging. The study focuses on the barriers that trigger the green purchasing gap and; identify which barriers are perceived as the most relevant in acquiring eco-friendly home appliances. The paper examines the measurement instrument (questionnaire) for validity and reliability, for the purpose of data analysis. Statistical techniques used for validity and reliability were Exploratory Factor Analysis and Cronbach's Alpha. Exploratory Factor Analysis was performed on individual dimension for the purpose of explaining variation among items and their reduction to form a meaningful construct.
\end{abstract}

Keywords - Eco-friendly, consumption barriers, green purchasing gap, Malaysian consumers, Exploratory factor analysis.

\section{Introduction}

The concept of sustainability has got extensive attention in the recent decades, people have become gradually aware of the necessity to reduce the environmental impact. However, empirical evidence shows that environmentally aware consumers seldom translate their "green" concerns and intentions into actual purchase behavior [1]. This arises with a question that why environmentally aware consumers rarely translate green concerns and intentions into actual purchase behavior $[2,3]$.

In recent decades, overconsumption of goods and services have grown immensely throughout the world, which has led to a number of environmental problems resulting to environmental degradation. Lately, the concept of environmentalism or sustainability has reformed to address new problems such as climate change, genetic engineering and overpopulation [4]. According to Tan, et al. [4], climate change is one of the leading environmental issues, which is widely discussed in conferences and international dialogues. To reduce climate change, one of the key initiatives is through the reduction of energy usage such as promoting eco-friendly products among consumers.

However, estimates reported the market share of eco-friendly products was less than four percent worldwide [5]. Moreover, sales for eco-friendly products seem to be trending downward. For example, Nature's Source sales have fallen by 50 percent over the past two years, while Clorox Green Works has seen a 40 percent decrease in sales [6]. This implies that there exists a lack of consumer acceptance of green products, which shows that there are several barriers to green consumption. This predicament is also of relevant concern for manufacturers of green products and society overall [2], since considerable resources are spent by both suppliers and the retailers to develop and sell green products [7]. For instance, Wal-Mart spends approximately $\$ 500$ million yearly for the development and implementation of green technologies [8]. However, regardless of firms' tremendous financial expenses, the massive majority of consumers do not purchase eco-friendly products [7]. Therefore, several recent studies, conducted on the cognitive and rational aspects of the green purchasing gap, have studied the presence of certain barriers (i.e. purchasing green products often involves high monetary and non-monetary costs) that may stop environmentally aware consumers from "walking their talk" [7, 9].

Moreover, recent research, investigating the cognitive and rational aspects of the green purchasing gap, has identified restraining factors, such as consumers' rationalizations $[10,11]$ and the existence of contextual barriers [9] that hinder the translation of environmental attitudes and environmental products purchase intentions into green purchase behavior. The "going green" trend has now prolonged to the Asian region [12], together with Malaysia. At large, Malaysian consumers are ever more willing to favor green ideas [13].

*Corresponding author: azhan_hasan@utp.edu.my

There is a rising attention on reducing energy usage and the accompanying greenhouse gas emissions in all sectors of the economy. Estimates have reported energy usage of the residential sector to account for $16-50 \%$ of 
that used up by all sectors, and at an average 30 percent approximately worldwide, where Malaysia stands 19 percent. This suggests that the residential sector is a extensive consumer of energy worldwide, and consequently the research focused on household energy consumption efforts.

Drawing from these statistics, it is necessary to find out the possible barriers which impede the green purchase and assess the role of those barriers in the purchase of eco-friendly home appliances. To date, studies on the consumers' perceived barriers in hampering the purchase of eco-friendly electronic home appliances, are very limited in Malaysia.

To investigate the barriers of green purchasing, a valid instrument is required to analyse green purchasing of eco-friendly home appliances. Several green consumption instruments have been described recently, but these instruments do not measure all the variables incorporated for this study [14-20]. Also, most of instruments were developed to assess either general green consumption behaviour or behaviour related to low-involvement products $[2,7,16]$. Whereas instrument required for this study should focus on high-involvement products (electronic home appliances). Consequently, there is a need to design and validate instrument, for the analysis of barriers of green purchasing of home appliances. To address these issues, we used a well-described process to develop and validate instrument that would allow analysis of barriers towards green purchase behavior.

Besides, survey was conducted from renown hypermarkets of Malaysia. Quantitative approach was used to design study. Since, assessment of instrument is also essential for the purpose of validity and reliability [21]. Therefore, this paper aims at validating and assessing the scale used to measure the constructs or variables of the study.

Thus, the objectives of the study are:

- Assess instrument (measurement items) for high involvement products (home appliances) for the factors (Price, social influence, trust, product attributes, product availability, eco labels and communication) through exploratory factor analysis (EFA);

- and analyzing reliability and validity of survey instrument.

Applying staistical techniques, would allow to test for validity and reliability of instrument adopted for the study. The statistical techniques used are discussed below.

EFA, a variable reduction technique, is used to explore the likely underlying factor structure of a set of observed variables (items) without imposing a predetermined structure on the outcome [22]. By carrying out EFA, the underlying factor structure is identified. It puts forward an underlying construct, a variable that is not measured directly (latent variable) and allows to identify and describe the number of latent constructs (factors) [23]. Also, EFA comprehends unique factors, which are errors due to unreliability in measurement and variation in data [23]. Consequently, it allows to test the reliability of scales as well. Also, this technique has been used because it helps in explaining variation among items, using few variables (factors), along with providing the meaning of factors (latent variables) [23].

Alpha is an essential concept in the evaluation of assessments and questionnaires [24]. According to Tavakol and Dennick [24], it is compulsory that researchers should evaluate Alpha value to add validity and accuracy to the interpretation of their data [24]. Cronbach's Alpha is used to measure internal consistency of a scale or test, expressed in the form of a number ranging from 0 to 1 [24]. Internal consistency defines the degree to which all the items of a test measure the same construct or concept and hence it is associated with the inter-relatedness of the items in the test [24]. Thus, provides the reliability and validity of the instrument.

\section{Study Variables}

To identify the barriers in the way of eco-friendly purchase behavior, present empirical research was examined, and systematic review of current literature was performed. The research design applied in the paper reviewed was mainly survey research.

The study focuses on number of barriers namely, price, social influence, trust, product attributes, availability, eco-labels, and communication as summarized in TABLE I. It is evident from the summary that most of the quantitative studies either focused on general green consumption or consumption of low-involvement products. 
TABLE I. Summary of Relevant Articles

\begin{tabular}{|c|c|c|c|c|}
\hline Barriers & Author(s) & Product & Method & Country \\
\hline \multirow[t]{5}{*}{ Price } & $\begin{array}{l}\text { Barbarossa \& } \\
\text { Pastore (2015) }\end{array}$ & $\begin{array}{l}\text { Eco-friendly Tissue } \\
\text { Paper Products } \\
\text { (EFTPP) }\end{array}$ & Qualitative & Italy \\
\hline & Gleim et al. (2013) & $\begin{array}{l}\text { General green } \\
\text { consumption* }\end{array}$ & Mix Method & USA \\
\hline & Young et al. (2010) & Technology Products & Qualitative & UK \\
\hline & Ozaki (2011) & Green Electricity & Mix Method & London \\
\hline & $\begin{array}{l}\text { Johnstone \& Tan } \\
\text { (2015) }\end{array}$ & $\begin{array}{l}\text { General green } \\
\text { consumption* }\end{array}$ & Quantitative & New Zealand \\
\hline \multirow[t]{3}{*}{ Social Influence } & Gleim et al. (2013) & $\begin{array}{l}\text { General green } \\
\text { consumption* }\end{array}$ & Mix Method & USA \\
\hline & Ozaki (2011) & Green Electricity & Mix Method & London \\
\hline & $\begin{array}{l}\text { Pickett-Baker \& } \\
\text { Ozaki (2008) }\end{array}$ & FMCG's & Quantitative & London \\
\hline \multirow[t]{3}{*}{ Trust } & Gleim et al. (2013) & $\begin{array}{l}\text { General green } \\
\text { consumption* }\end{array}$ & Mix Method & USA \\
\hline & $\begin{array}{l}\text { Gupta \& Ogden } \\
\text { (2009) }\end{array}$ & Energy Conservation & Quantitative & USA \\
\hline & $\begin{array}{l}\text { Johnstone \& Tan } \\
(2015)\end{array}$ & $\begin{array}{l}\text { General green } \\
\text { consumption* }\end{array}$ & Quantitative & New Zealand \\
\hline \multirow{5}{*}{$\begin{array}{l}\text { Product Attributes } \\
\text { (Low quality, low } \\
\text { performance) }\end{array}$} & Gleim et al. (2013) & $\begin{array}{l}\text { General green } \\
\text { consumption* }\end{array}$ & Mix Method & USA \\
\hline & Young et al. (2010) & Technology Products & Qualitative & UK \\
\hline & $\begin{array}{l}\text { Gupta \& Ogden } \\
\text { (2009) }\end{array}$ & Energy Conservation & Quantitative & USA \\
\hline & $\begin{array}{l}\text { Pickett-Baker \& } \\
\text { Ozaki (2008) }\end{array}$ & FMCG's & Quantitative & London \\
\hline & $\begin{array}{l}\text { Johnstone \& Tan } \\
\text { (2015) }\end{array}$ & $\begin{array}{l}\text { General green } \\
\text { consumption* }\end{array}$ & Quantitative & New Zealand \\
\hline Lack of Availability & Young et al. (2010) & Technology Products & Qualitative & UK \\
\hline \multirow{2}{*}{$\begin{array}{l}\text { Confused Eco- } \\
\text { labels }\end{array}$} & Young et al. (2010) & Technology Products & Qualitative & UK \\
\hline & $\begin{array}{l}\text { Pickett-Baker \& } \\
\text { Ozaki (2008) }\end{array}$ & FMCG's & Quantitative & London \\
\hline Communication & $\begin{array}{l}\text { Barbarossa \& } \\
\text { Pastore (2015) }\end{array}$ & $\begin{array}{l}\text { Eco-friendly Tissue } \\
\text { Paper Products } \\
\text { (EFTPP) }\end{array}$ & Qualitative & Italy \\
\hline
\end{tabular}

*Studied in general. No product was specified.

There is need to explore the study variables as Gleim et al. (2013) suggested regarding price and social influence that future research is needed on the issues of green price sensitivity and the role of personal norms on the diffusion of eco-friendly products. On the other hand, Carrete, et al. [25] in 2012, noted that social influence, 
environmental concern and perceived consumer effectiveness of environmental behaviour are the most significant predictors of individuals' green purchasing behaviour. In this regard, Social Influence and PCE have been considered for this study. Also, the arrangement of adopted variables and their effect in terms of drivers and moderating variables is different from previous researches, in addition, these variables are adopted from different studies and will be tested together on dependent variable (see TABLE I).

Price Researches have reflected that several things effect consumers' decision-making, but perhaps the strongest influences are the expenses associated with green buying [11,26]. The economic influences that effect individuals consist of more than just price, i.e. the effort and time needed to search and assess goods and services are part of the cost incurred in consuming that product [7]. For individuals to hold desirable behaviors, the apparent ratio of costs to benefits (i.e., value) given to green products must be better than that of substitutes [27]. Thus, theory proposes that if individuals feel that environmental products are priced too high, environmental buying is impeded. As environmental products are seen to be significantly more expensive than conventional products [28], it is probable that price discourages many non-green consumers. Furthermore, most individuals see higher prices related with energy star rated appliances but do not assume forthcoming cost savings [7]. Thus, consumers choose alternatives that have a lower initial financial expenditure not realising another choice is inexpensive in the long run though also being advantageous for the environment [7]. Since price has been studied as a barrier in most of the researches on green consumption, however there is need to explore whether it moderates consumers green purchase of eco-friendly home appliances or not.

Social Influence Since environmental products often comprise higher costs (e.g., higher prices, information search, or performance risk), the acquisition of such items makes a social dilemma for consumers. Thus, consideration of social effects on the buying of green goods and services is likewise an important aspect. It is anticipated that reference group will effect green purchase behavior [20]. If a group to which an individual belongs to or aspires to belong to, displays behaviors consistent with their pro-environmental attitude, the person is under more pressure to imitate [20]. In disparity when a reference group does not display consistent behaviors, the person is less expected to interpret their own behavior into action [20]. Thus, it is of importance to investigate, whether social influence acts as a barrier to green purchasing.

Trust Besides, consumers' loyalty to a conventional (i.e., non-green) product may be unwilling to experience the cognitive costs of searching out, and assessing the information required to evaluate, available substitute to a currently used product [7]. Research further submits that consumers do not want to be perceived as a "sucker" [29], which could be the situation if a eco-friendly product fails to meet their standards. The effort and time needed to seek and assess green alternates, as well as the cognitive and economic risks related with eco-friendly product failures, possible further discourages eco-friendly consumption. Several studies reported that lack of consumer trust and characteristics of green products and confidence in green claims was a noteworthy barrier of green purchasing [30-32], however these researches focused on low invovement products. Subsequently, it is of great concern, whether lack of consumer trust effects low involvement green purchasing.

Product Attributes Consumers, also consider product attributes while involving in the purchase of green products [19]. Consumers prefer functional attributes of the product (that fulfil personal needs and desires) over its ethical characteristics [33]. Therefore, conscious consumers are expected to engage in green consumption, if functional features are well-preserved as consumers do not agree with trading basic functional attributes for environmentally acceptable attributes [33]. Similarly, if consumers assume green products to have poor product attributes and substandard quality, may result in a conflict between personal needs of consumers and their sense of environmental and social responsibility, which may further increase the inconsistency between attitude and actual green buying [34].

Product Availability Carrington, et al. [35] and Gleim, et al. [7] recognized the lack of product availability, higher prices, lower quality and a small product range of environmental brands as explanations for the lack of green purchasing. Studies on green consumption revealed that in spite of showing concern towards the environment, the consumers were not willing to buy or pay more for eco-friendly products [36, 37]. Thus, lack of product availability can inhibit consumers from actual green purchasing. But it is of concern yet, whether it is as influential as other factors in stopping consumers from purchasing green.

Eco-labels On the other hand, Pickett-Baker and Ozaki [16] revealed that it is not easy for consumers to identify eco-friendly products. Whereas, D'Souza, et al. [17] continued that a noteworthy percentage of consumers find eco-friendly product labels hard to understand. A propagation of unclear green labels "may confuse consumers and weaken reliability" [38]. But do eco-labels act as barrier towards green purchasing is yet to be investigated.

Communication Pinkse and Dommisse [39] specified that organizations should gradually communicate the benefits of eco-friendly products and clean technologies to possible buyers to generate market demand. Besides, 
skepticism [40] and a lack of information [41] have also been recognized as significant barriers to the purchase of eco-friendly products. Further, communication failures are observed to leave consumers unaware of the existence of eco-products [2]. It should be identified, whether communication failure is a barrier in case of eco-home appliances purchasing.

Perceived Consumer Effectiveness A consumer's belief that s/he makes an impact or difference to the environment by purchasing eco-friendly products is known as PCE (perceived consumer effectiveness) [42]. Research proposes that PCE is a significant predictor of eco-friendly consumption [43]. Individuals that strongly believe they cannot make an impact (i.e., high PCE) are more expected to purchase non-green products [7]. Thus, it is expected, if it is the strongest influencer for non-green purchasing.

\section{Methodology}

\subsection{Sample and procedure}

The respondents chosen for the study were buyers in Perak. It was determined that the sample population be designed by consumers above the age of 29 -years-old. The purpose was individuals over this age are aware with buying of products and are also empowered in their choices for selecting the right products among various available choices, therefore, thoughtful to environmental issues in their purchasing behaviour. A quantitative approach is adopted, as the study intents to test a theory. The method of data collection was a structured questionnaire. The survey was distributed in the main hypermarkets in Perak where people are exposed to diverse range home appliances. A total 392 individuals in Perak participated in the present study.

\subsection{Research Instrument and Method}

A quantitative method was adopted for the study, through the use of self- administered survey questionnaires. A well-structured close-ended questionnaire comprised of items on demographics, consumer purchase attitude, consumer purchase behavior and drivers (barriers) that influence consumer purchase attitude of green purchasing. Data collected on items of barriers (independent variables) will be used to find the relevance of different barriers that impede green purchase behavior of consumers. Following TABLE II. Lists the sources from where items on research instrument are adopted.

TABLE II. Sources for items on Survey Instrument.

\begin{tabular}{|c|c|l|}
\hline Sr. NO. & Variable & \multicolumn{1}{c|}{ Reference } \\
\hline $\mathbf{1}$ & Trust & $\begin{array}{l}\text { Pickett-Baker and Ozaki [16] } \\
\text { Tanner and Wölfing Kast [44] }\end{array}$ \\
\hline $\mathbf{2}$ & Product attributes & $\begin{array}{l}\text { Kong, et al. [15] } \\
\text { Pickett-Baker and Ozaki [16] } \\
\text { D'Souza, et al. [17] }\end{array}$ \\
\hline $\mathbf{3}$ & Social Influence & Wu [14] \\
\hline $\mathbf{4}$ & Lack of product availability & Gleim, et al. [7] \\
\hline $\mathbf{5}$ & Brand Image & $\begin{array}{l}\text { Rahbar and Abdul Wahid [18] } \\
\text { Pickett-Baker and Ozaki [16] } \\
\text { D'Souza, et al. [17] }\end{array}$ \\
\hline $\mathbf{6}$ & Eco-labels & $\begin{array}{l}\text { Kong, et al. [15] } \\
\text { D'Souza, et al. [17] } \\
\text { Tanner and Wölfing Kast [44] }\end{array}$ \\
\hline $\mathbf{7}$ & & Pickett-Baker and Ozaki [16] \\
\hline $\mathbf{8}$ & Communication & Wu [14] \\
\hline $\mathbf{9}$ & PCE (Perceived Consumer Effectiveness) & $\begin{array}{l}\text { Chan [45] } \\
\text { Tanner and Wölfing Kast [44] }\end{array}$ \\
\hline $\mathbf{1 0}$ & Green Purchase Attitude & $\begin{array}{l}\text { D'Souza, et al. [17] } \\
\text { Tanner and Wölfing Kast [44] }\end{array}$ \\
\hline $\mathbf{1 1}$ & Price & Chan [45] \\
\hline & Green Purchase Behaviour & \\
\hline
\end{tabular}

A 6 point-likert scale was adopted as uncertain and neutral response categories tend to be used more often on 3- and 5-point scales [46]. Also, findings of Leung [47] suggest that having more points scale seems to decrease skewness. 
The assessment of instrument is essential as it delivers systematic testing for the validity and reliability of the scales measuring the latent constructs and their apparent variables [21]. Thus, exploratory factor analysis and Cronbach's Alpha were performed. The validated and reliable data will then be analyzed using PLS-SEM (Partial Least Squares Structural Equation Modelling).

\section{Findings \& Discussion}

\subsection{Factor Analysis}

In order to investigate the constructs' dimensions, EFA (Exploratory Factor Analysis) was initially carried out to verify if the anticipated factor structures are consistent with the original data. EFA was run on eleven study variables, analyzing each variable separately, to provide information whether the items represent the same factor. The extraction method adopted was Principal Component Analysis with Promax rotation.

The outcomes of the Exploratory Factor Analysis justified the necessity to remove certain items from the instrument. The outstanding fifty-four factors loaded as anticipated onto their dimensions out of total sixty-two items.

The items used to measure the independent and dependent variables were entered in multiple exploratory factor analysis i.e. the same exploratory factor analysis technique was used on the individual dimension. All factors fall under single component with variances. Few items were removed, which either had low cross loading $(<0.3)$ or factor loading below 0.5. All the remaining items extended to the analysis show good factor loadings with value greater than 0.5 . The factor structures indicated by exploratory factor analysis results, resembles the one proposed in the research model. III.

After the application of factor analysis, the properties of the measurement model are summarized in TABLE

TABLE III. Summary of Constructs

\begin{tabular}{|l|c|c|c|}
\hline \multicolumn{1}{|c|}{ Construct Name } & $\begin{array}{c}\text { Initial Number of } \\
\text { Items }\end{array}$ & $\begin{array}{c}\text { Number of Items carried } \\
\text { forward to the Analysis }\end{array}$ & Cronbach's Alpha \\
\hline Trust & 6 & 5 & 0.771 \\
\hline Product Attributes & 6 & 5 & 0.789 \\
\hline Lack of Product Availability & 3 & 4 & 0.548 \\
\hline Brand Image & 5 & 5 & 0.605 \\
\hline Eco-Labelling & 5 & 5 & 0.792 \\
\hline Communication & 6 & 3 & 0.858 \\
\hline Social Influence & 6 & & 0.73 \\
\hline Perceived Consumer & 5 & 5 & 0.856 \\
Effectiveness & 9 & 9 & 0.921 \\
\hline Green Purchase Attitude & 5 & 5 & 0.829 \\
\hline Price & 6 & 5 & 0.873 \\
\hline Green Purchase Behaviour & & & \\
\hline
\end{tabular}

\subsection{Assessment of Measurement Models}

The evaluation of instrument is important and necessary since it delivers detailed testing for the validity and reliability of the scales used for measuring the latent constructs and their apparent variables [21]. Few steps were followed for the evaluation of the measurement model. Firstly, exploratory factor analysis using principal component analysis was performed.

Subsequently, followed by evaluation of convergent validity, and assessment of the measure's reliability. 
Validity and Reliability of Instrument Process for scale development was followed, in order to test the validity and reliability of the study constructs [48]. First, convergent validity was assessed and then reliability of the scale items was assessed.

\subsubsection{Convergent Validity}

Convergent validity postulates that items that are indicators of a construct should share a high fraction of variance [49]. The convergent validity of the scale items was evaluated using two criteria. Firstly, as suggested by Hair, et al. [49] the factor loadings should be greater than 0.50 . Second, the composite reliability for each construct should exceed 0.70 .

In this study, the factor loadings for constructs demonstrated support for convergent validity for the eleven constructs. All loadings for constructs were above 0.50 , with most of them greater than 0.60 . The overall factor loadings between 0.562 to 0.929 . Items with factor loadings below 0.70 can yet be measured significant, but more percentage of the variance in a certain measure is credited to error [49]. The high factor loadings provide justification to infer that the measures considered have convergent validity.

\subsubsection{Reliability of Measures}

The last stage in examining construct validity is to assess the reliability of the construct items. Reliability is stated as the extent to which a group of indicators are internally consistent, the degree to which the measuring instrument holds the same results on frequent trials. Reliability is essential but not adequate enough for validation of a measure, even though measures with high value for reliability might not prove valid when measuring the construct of importance [49]. Reliable indicators should be measuring the same construct. Construct reliability coefficients should all lie beyond the 0.70 lower limits $[48,49]$. However, values as low as 0.50 are satisfactory for initial construct development as proposed by Nunnally and Bernstein [50], and . Moreover, Van de Ven [51] found that satisfactory values can be as low as 0.40 for widely defined constructs. The Cronbach's alpha values for the constructs studied were calculated by SPSS and ranged from 0.548 to 0.921 .

Thus, it is evidently specified that all the variables employed for this research are reliable as they attained the Cronbach's Alpha values greater than 0.7 with an exception of .548 and .605 for lack of product availability and brand image constructs, respectively. All values for Cronbach's Alpha fall within the range that is acceptable to conclude good reliability.

\section{Conclusion}

The evaluation of measuring instrument is essential to have information about the validity and reliability of the scales used for measuring the latent constructs and their apparent variables [21]. Validity and reliability of the instrument was achieved using some statistical tests i.e. exploratory factor analysis with principal component extraction and Cronbach's Alpha for reliability.

EFA is a form of multivariate analysis, which is used to describe the underlying structure termed as factors among the variables in the analysis [49]. Factor analysis was utilized on eleven study variables, analyzing each variable separately, to provide information whether the items represent the same factor. The extraction method adopted was PAF (Principal axis factoring) to look into factor loading. The items were retained with factor loading above 0.5 . Consequently, this technique facilitated in explaining variation among items and reducing them to a meaningful set of items to define latent variable.

Cronbach's Alpha were analyzed then for reliability and validity of scales. Alpha is an important concept in the evaluation of assessments and questionnaires [24]. As stated by Tavakol and Dennick [24], it is obligatory that researchers should evaluate Alpha value to add validity and accuracy to the interpretation of their data [24]. All the variables employed to measure were found reliable as they attained Cronbach's Alpha greater than 0.7, with an exception of .548 and .605 for lack of product availability and brand image constructs, respectively. As suggested by Nunnally and Bernstein [50] and regarding Cronbach's Alpha, that values below 0.50 are considered acceptable for initial construct development. Thus, all values for variables studied fall under the acceptable range to justify good reliability. 


\section{References}

[1] Bank, C. O. (2012). Ethical consumerism report 2011. Cooperative Bank UK.

[2] Barbarossa, C., \& Pastore, A. (2015). Why environmentally conscious consumers do not purchase green products: a cognitive mapping approach. Qualitative Market Research: An International Journal, 18(2), 188-209.

[3] Nielsen (2013). "Will a desire to protect the environment translate into action?," (Edited).

[4] Tan, C. S., Ooi, H. Y., \& Goh, Y. N. (2017). A moral extension of the theory of planned behavior to predict consumers' purchase intention for energy-efficient household appliances in Malaysia. Energy Policy, 107, 459-471.

[5] Dupré, S. (2005). Talk the walk: Advancing sustainable lifestyles through marketing and communications. UNEP/Earthprint.

[6] Clifford, S., \& Martin, A. (2011). As consumers cut spending, 'green'products lose allure. New York Times, 21.

[7] Gleim, M. R., Smith, J. S., Andrews, D., \& Cronin Jr, J. J. (2013). Against the green: a multi-method examination of the barriers to green consumption. Journal of retailing, 89(1), 44-61.

[8] Fetterman, M. (2006). Wal-Mart grows 'green’strategies. USA Today, 9(25), 2006.

[9] Bray, J., Johns, N., \& Kilburn, D. (2011). An exploratory study into the factors impeding ethical consumption. Journal of business ethics, 98(4), 597-608.

[10] Eckhardt, G., Devinney, T., \& Belk, R. (2006). Why don't consumers behave ethically?: the social construction of consumption. AGSM.

[11] Eckhardt, G. M., Belk, R., \& Devinney, T. M. (2010). Why don't consumers consume ethically?. Journal of Consumer Behaviour, 9(6), 426-436.

[12] Lee, K. (2008). Opportunities for green marketing: young consumers. Marketing intelligence \& planning, 26(6), 573-586.

[13] Sinnappan, P., \& Rahman, A. A. (2011). Antecedents of green purchasing behavior among Malaysian consumers. International Business Management, 5(3), 129-139.

[14] Wu, S. I. (2015). Effect of green consumption perception degree on relationship model of green consumption behavior. Journal of Management and Strategy, 6(2), 109.

[15] Soon, T., \& Kong, W. (2012). The Influence of Consumer's Perception of Green Products on Green Purchase Intention(Doctoral dissertation, Universiti Malaysia Sabah).

[16] Pickett-Baker, J., \& Ozaki, R. (2008). Pro-environmental products: marketing influence on consumer purchase decision. Journal of consumer marketing, 25(5), 281-293.

[17] D'Souza, C., Taghian, M., \& Lamb, P. (2006). An empirical study on the influence of environmental labels on consumers. Corporate communications: an international journal, 11(2), 162-173.

[18] Rahbar, E., \& Abdul Wahid, N. (2011). Investigation of green marketing tools' effect on consumers' purchase behavior. Business strategy series, 12(2), 73-83.

[19] Young, W., Hwang, K., McDonald, S., \& Oates, C. J. (2010). Sustainable consumption: green consumer behaviour when purchasing products. Sustainable development, 18(1), 20-31.

[20] Gupta, S., \& Ogden, D. T. (2009). To buy or not to buy? A social dilemma perspective on green buying. Journal of Consumer Marketing, 26(6), 376-391.

[21] Loehlin, J. C. (1998). Latent variable models: An introduction to factor, path, and structural analysis. Lawrence Erlbaum Associates Publishers.

[22] Child, D. (1990). The essentials of factor analysis. Cassell Educational.

[23] Suhr, D. D. (2006). Exploratory or confirmatory factor analysis?.

[24] Tavakol, M., \& Dennick, R. (2011). Making sense of Cronbach's alpha. International journal of medical education, 2, 53.

[25] Carrete, L., Castaño, R., Felix, R., Centeno, E., \& González, E. (2012). Green consumer behavior in an emerging economy: confusion, credibility, and compatibility. Journal of consumer marketing, 29(7), 470481.

[26] Osterhus, T. L. (1997). Pro-social consumer influence strategies: when and how do they work?. The Journal of Marketing, 16-29. 
[27] Geller, E. S. (1992). It takes more than information to save energy.

[28] Kavilanz, P. B. (2008). The High Price of Going'Organic'. CNNMoney. com, 2.

[29] Sen, S., Gürhan-Canli, Z., \& Morwitz, V. (2001). Withholding consumption: A social dilemma perspective on consumer boycotts. Journal of Consumer research, 28(3), 399-417.

[30] Tung, S. J., Shih, C. C., Wei, S., \& Chen, Y. H. (2012). Attitudinal inconsistency toward organic food in relation to purchasing intention and behavior: An illustration of Taiwan consumers. British Food Journal, 114(7), 997-1015.

[31] Krystallis, A., Vassallo, M., Chryssohoidis, G., \& Perrea, T. (2008). Societal and individualistic drivers as predictors of organic purchasing revealed through a portrait value questionnaire (PVQ)-based inventory. Journal of Consumer Behaviour: An International Research Review, 7(2), 164-187.

[32] Vermeir, I., \& Verbeke, W. (2008). Sustainable food consumption among young adults in Belgium: Theory of planned behaviour and the role of confidence and values. Ecological economics, 64(3), 542-553.

[33] Chen, J., \& Lobo, A. (2012). Organic food products in China: determinants of consumers' purchase intentions. The International Review of Retail, Distribution and Consumer Research, 22(3), 293-314.

[34] Joshi, Y., \& Rahman, Z. (2015). Factors affecting green purchase behaviour and future research directions. International Strategic Management Review, 3(1-2), 128-143.

[35] Carrington, M. J., Neville, B. A., \& Whitwell, G. J. (2014). Lost in translation: Exploring the ethical consumer intention-behavior gap. Journal of Business Research, 67(1), 2759-2767.

[36] Ottman, J. A. (1993). Industry's response to green consumerism: Journal of Business Strategy, 13 (4), 3-7 (July/August 1992). Long Range Planning, 26(1), 153.

[37] Schlossberg, H. (1992). Kids teach parents how to change their buying habits. Marketing News, 26(8).

[38] De Pelsmacker, P., Driesen, L., \& Rayp, G. (2005). Do consumers care about ethics? Willingness to pay for fair-trade coffee. Journal of consumer affairs, 39(2), 363-385.

[39] Pinkse, J., \& Dommisse, M. (2009). Overcoming barriers to sustainability: an explanation of residential builders' reluctance to adopt clean technologies. Business Strategy and the Environment, 18(8), 515527.

[40] Carrigan, M., \& Attalla, A. (2001). The myth of the ethical consumer-do ethics matter in purchase behaviour?. Journal of consumer marketing, 18(7), 560-578.

[41] Hamzaoui Essoussi, L., \& Zahaf, M. (2009). Exploring the decision-making process of Canadian organic food consumers: Motivations and trust issues. Qualitative Market Research: An International Journal, 12(4), 443-459.

[42] Webster Jr, F. E. (1975). Determining the characteristics of the socially conscious consumer. Journal of consumer research, 2(3), 188-196.

[43] Roberts, J. A. (1996). Green consumers in the 1990s: profile and implications for advertising. Journal of business research, 36(3), 217-231.

[44] Tanner, C., \& Wölfing Kast, S. (2003). Promoting sustainable consumption: Determinants of green purchases by Swiss consumers. Psychology \& Marketing, 20(10), 883-902.

[45] Chan, R. Y. (2001). Determinants of Chinese consumers' green purchase behavior. Psychology \& marketing, 18(4), 389-413.

[46] Matell, M. S., \& Jacoby, J. (1972). Is there an optimal number of alternatives for Likert-scale items? Effects of testing time and scale properties. Journal of Applied Psychology, 56(6), 506.

[47] Leung, S. O. (2011). A comparison of psychometric properties and normality in 4-, 5-, 6-, and 11point Likert scales. Journal of Social Service Research, 37(4), 412-421.

[48] Rossiter, J. R. (2002). The C-OAR-SE procedure for scale development in marketing. International journal of research in marketing, 19(4), 305-335.

[49] Hair, J. F., Anderson, R. E., Babin, B. J., \& Black, W. C. (2010). Multivariate data analysis: A global perspective (Vol. 7): Pearson Upper Saddle River.

[50] Nunnally, J. C., \& Bernstein, I. H. (1978). Psychometric Theory McGraw-Hill New York Google Scholar.

[51] de Ven, V., \& Ferry, A. H. (1980). DL, 1980. Measuring and Assessing Organizations. 